\title{
Anatomical changes of roots and steams of Phaseolus vulgaris L. (Fabales Fabaceae) under salinity at juvenile state
}

\author{
Tahri Miloud',Arbaoui Mohamed ${ }^{*}$, Yahia Nourredine² \& Chadli Rabah' \\ ${ }^{1}$ Department of Biology, Faculty of Natural and Life Sciences, University Abdelhamid Ibn Badis, Mostaganem, Algeria \\ ${ }^{2}$ Department of Biology, Faculty of Natural and Life Sciences, University Ahmed Ben Bella. Oran 1, Algeria \\ *Corresponding author, e-mail: mohamed.arbaoui@univ-mosta.dz
}

\begin{abstract}
In Algeria, the region of Mostaganem is known for its agricultural soils with a sandy tendency and abnormally loaded with soluble salts affecting the yields of crops. To assess the salt tolerance threshold of the bean culture Phaseolus vulgaris L. (Fabales Fabaceae) variety "coco rose" was grown in plastic pots filled with two types of substrate, sand and sand amended with $7 \%$ bentonite (calcium clay of mining origin). The test was carried out in a greenhouse with controlled climatic conditions (variant temperature between $23-25^{\circ} \mathrm{C}$, humidity is around $75 \%$ and a photoperiod of 12 hours). At the 5-leaf stage, irrigation with saline was provided with four saline concentrations $(0,50,100$ and $200 \mathrm{meq})$, the control is irrigated with distilled water. Two weeks later, the microscopic observations were made with an Optica type microscope, the results show a variability of the effect of saline stress depending on the organ and the concentration of the saline treatment. The anatomical structure of the treated roots and stems has shown significant anomalies; thus, the changes are marked by the decrease in the size of the parenchymal cells, that of the diameter of the xylem vessels and the increase in their number, under the action saline concentration $\left(\mathrm{NaClCaCl}_{2}\right)$ and according to the type of culture substrate sand $(\mathrm{S})$ and sand with bentonite $(\mathrm{SB})$.
\end{abstract}

KEY WORDS Anatomy; Bentonite; Salinity; Phaseolus vulgaris.

Received 31.05.2020; accepted 20.11.2020; published online 23.12.2020

\section{INTRODUCTION}

Salinity is one of the major abiotic environmental stresses affecting about $6-7 \%$ of the world's total land area and agricultural productivity specifically in arid and semi-arid regions of the world (Qadir et al., 2006). In saline soils, high concentrations of sodium $(\mathrm{Na})$ and chlorine $(\mathrm{Cl})$ ions within the plant root zone retards the growth of plants by either decreasing the water potential of root media or causing toxicity of $\mathrm{Na}$ and $\mathrm{Cl}$ in various plant organs (Panta et al., 2014). Salt impose both osmotic and ionic stresses on the plants which lead to several morphological and physiological changes (Jampeetong \& Brix, 2009). A clear stunting of plants is noticed due to salinity stress (Takemura et al., 2002). High salt content, especially chloride and sodium sulphates, affects plant growth by modifying their morphology and anatomy (Huang \& Redmann, 1995; Dolatabadian et al., 2011). The effect of salinity on root (An et al., 2003) and shoot anatomy (Ali et al., 1999) of plants had already been reported in previous works. Many researchers reported that with an increase in salinity there was a decrease in the development of the xylem. Pimmongkol et al. (2002) stated that the width of vascular bundles and 
diameters of rice stems decreased in $\mathrm{NaCl}$ medium. The earliest response is a reduction in the rate of expansion of the leaf surface, followed by cessation of expansion as stress increases (Parida \& Das, 2005). Munns \& Tester (2008) reported that saltsensitive plants have reduced survival, growth and development when exposed to even low to moderate salinities, while salt-tolerant species are able to grow and reproduce in saline environments.

The aim of this work is to study the effect of salinity not only at the scale of different soils, but also on the mechanisms of response of the plant Phaseolus vulgaris L. (Fabales Fabaceae) at different concentrations of $\mathrm{NaClCaCl}_{2}$ on sandy soil with or without bentonite. An anatomical study of stems and roots, microscopic visualization and examination of possible correlations between anatomical changes and salinity levels were done.

\section{MATERIAL AND METHODS}

\section{Plant materials and culture mode}

Phaseolus vulgaris L. coco rose variety is used as plant material for this experience.

The crop is grown in two different types of substrate: sand and sand mixed with $7 \%$ of bentonite clay mineral of calcium origin). The substrate is placed in plastic pots of $15 \mathrm{~cm}$ diameter and $20 \mathrm{~cm}$ height with a capacity of $2 \mathrm{~kg}$.

\section{Preparation of the culture substrate}

The sand is washed beforehand with dilute hydrochloric acid N, rinsed thoroughly with distilled water to remove the chlorides and dried in an oven at $105^{\circ} \mathrm{C}$. Thus prepared, the sand constitutes a support of the plant (1 plant per pot), allows aeration of the roots and has the advantage of not fixing the ions. After natural drying, the bentonite is crushed then mixed with the sand with a dose of $7 \%$. The Sand-Bentonite mixture is carefully homogenized manually, then filled into the pots. Beforehand the bottom of the pots is lined with a layer of one $\mathrm{cm}$ thick gravel of $0.5 \mathrm{~cm}$ in diameter serving as drains. On this layer is deposited a gas strip to retain the sand. Phaseolus seedlings were grown for 1 month, and watering with nutrient solution Hoagland \& Arnon (1938). The saline solution consists of two salts $\mathrm{NaCl}$ and $\mathrm{CaCl}_{2}$ concentrations $(50,100$, and $200 \mathrm{meq}$ ), the control is sprayed with the nutrient solution. The stress is applied at the 5-leaf stage and then repeated at a frequency of one intake per three days for three weeks.

\section{Anatomical study of stems and roots}

After each treatment, one seedling per pot is dug up and stripped of the substrate by rinsing with distilled water. This operation is repeated three times per treatment. The organs (stems and roots) are carefully separated by means of a razor blade and then cut into pieces 1 to $2 \mathrm{~cm}$ long. Only the samples of the median parts are taken into consideration. Cross sections are performed "freehand" on stems and roots by means of a razor blade. Thin sections with a thickness of $20 \mu \mathrm{m}$ are stained by the double staining technique (methyl green/Congo red). The sections are first treated with $8 \%$ sodium hypochlorite for 15 minutes. After careful rinsing with distilled water, they are etched with dilute 70\% acetic acid for 2 minutes and then stained with $1 \%$ methyl green for 5 minutes; the latter colors the lignified walls in green. The pieces are then washed with distilled water and stained with $2 \%$ Congo red for 15 minutes. This dye highlights the cellulose that appears in pink or red.

\section{Double staining technique}

The sections are then washed with distilled water and mounted in a drop of water between the slide and coverslip before being observed first under ordinary microscope, then on another microscope allowing good shooting and taking pictures. The cups are kept either in pillboxes containing distilled water or in a drop of Canada balm placed between blade and coverslip. Once the sections are stained, they are observed by a microscope of the type Optica menu of apparatus of high definition in taking microscopic photo; a photo tube used for taking micrographs.

\section{Statistical analysis}

An experimental design of plots in complete random block was carried out using 3 plants per treatment. Three roots and three stems per plant were sampled for anatomical studies. Data were an- 
alyzed by ANOVA using the Newman-Keuls Least Significant Difference Test (LSD) for mean comparisons using a significance level of $5 \%$.

\section{RESULTS}

The sections obtained, used as experimental material under observation under a microscope, made it possible to measure the cells of conducting vessels specifically the root and shoot xylem. These measurements concerned measurements of the diameter of the vessels using a micrometer adapted to the microscope.

To show the effect of salinity on the evolution of the root diameter of the cylinder vessels of the bean variety tested, observations under a microscope are made on seedlings grown in substrate without bentonite (Fig. 1). The results obtained show a root cylinder diameter of $(27.2 \mu \mathrm{m})$ in the control, this diameter decreases significantly under the effect of salinity to reach $(8.77 \mu \mathrm{m})$ at $200 \mathrm{meq}$ of $\mathrm{NaClCaCl}_{2}$ (Table 1). Observations using the microscope at magnification (X40), the photos in the figure 3 ( $a, b, c$ and d) clearly show a very significant reduction in the diameter of the vessels of the root cylinder under the salinity effect.

The anatomy of the stem gives us structural changes in the cylinder elements. After 21 days of growth in the substrate without bentonite, the bean seedlings stressed with $\mathrm{NaClCaCl}_{2}$ register diameters of the cylinder cells substantially identical in the control and at $50 \mathrm{meq}$ around $20 \mu \mathrm{m}$. As soon as the salinity increases in the culture medium, the measurements made on the cells of the stem cylinder give a diameter which decreases sharply to reach $(13.5 \mu \mathrm{m})$ at $100 \mathrm{meq}$, then $(8.9 \mu \mathrm{m})$ at 200 meq (Table 2). These observations are confirmed with the anatomical study; thus, anatomical sections are made on the stems of bean seedlings aged 21 days grown in sand alone and stressed with $\mathrm{Na}$ $\mathrm{ClCaCl}_{2}$. Microscopic observations at magnification (X40) show variations in the number of cylinder vessel cells (Fig. 2). This explains why, when the salinity increases in the culture medium, the number of cells per vessel decreases as well as their diameter.

As shown in figure 3, results indicate the influence of salinity on the variation of the root xylem diameter of the vessels. After 21 days of growth, the roots of the bean variety have a maximum diameter of the xylem vessels with $(27.2$ and $28.13 \mu \mathrm{m})$ by the control, on the other hand, at the $200 \mathrm{meq}$ of Na$\mathrm{ClCaCl}_{2}$, these diameters decrease to give a minimum of 8.83 and $17.03 \mu \mathrm{m}$ grown respectively on $\mathrm{S}$ and SB substrate. The sand amended with bentonite made it possible to display larger xylem diameters than those of the substrate without bentonite with 23.5 and $19.37 \mu \mathrm{m}$ against 17.67 and $13.43 \mu \mathrm{m}$ respectively at $50 \mathrm{meq}$ and $100 \mathrm{meq}$ of $\mathrm{NaClCaCl}_{2}$. Statistical calculations show that

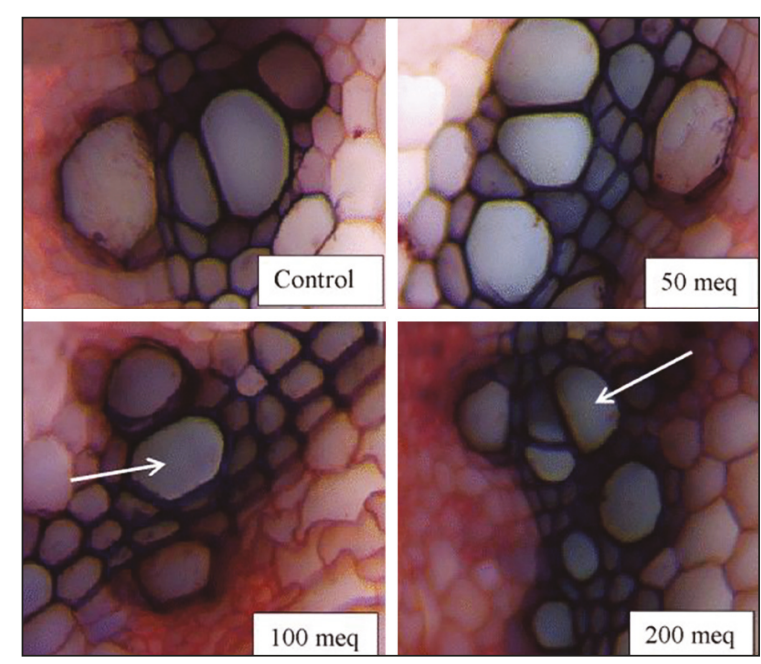

Figure 1. Root anatomy of Phaseolus vulgaris L. variety "coco rose", 21 days old. The arrows indicate the xylem vessels (magnificationX40).
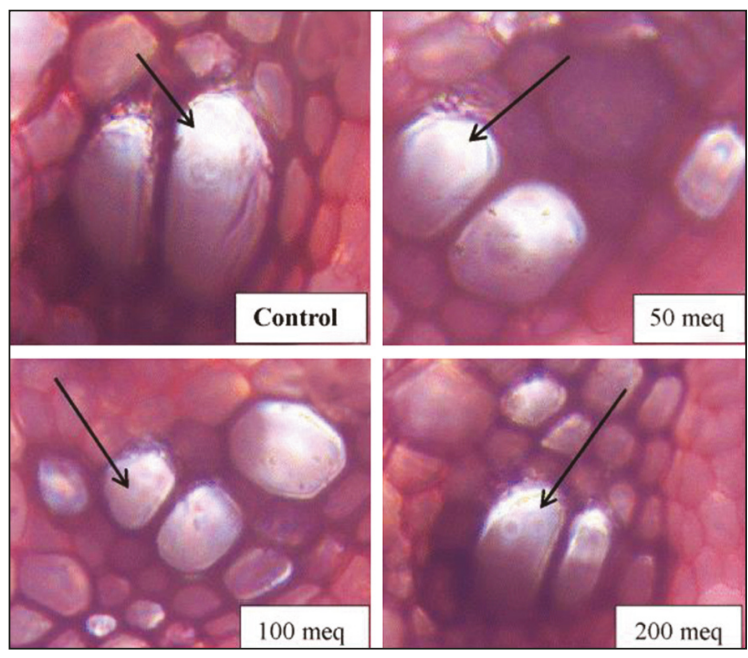

Figure 2. Stem anatomy of Phaseolus vulgaris L. variety "coco rose", 21 days old. The arrows indicate the xylem vessels (magnificationX40). 


\begin{tabular}{|ccccc|}
\hline Substrate & Control & $\mathbf{5 0 ~} \mathbf{~ m e q}$ & $\mathbf{1 0 0} \mathbf{~ m e q}$ & $\mathbf{2 0 0} \mathbf{~ m e q}$ \\
\hline WOB $* * *$ & $27.2^{\text {a ns }}$ & $17.67^{\mathrm{b}}$ & $13.43^{\mathrm{d}}$ & $8.77^{\mathrm{f}}$ \\
WB $^{* * *}$ & $28.13^{\text {a ns }}$ & $23.5^{\mathrm{c}}$ & $19.37^{\mathrm{e}}$ & $17.03^{\mathrm{g}}$ \\
\hline
\end{tabular}

Table 1. Effect of salinity and substrate on root cylinder diameter $(\mu \mathrm{m})$ of Phaseolus vulgaris L. Means in each row followed by different letters are significantly different $(\mathrm{p}<0.05)$. *,**,*** Differences between substrate is significant at $\mathrm{P}<0.05$, 0.01 , and 0.001 respectively, ns: not significant at $(\mathrm{P}<0.05)$.

\begin{tabular}{|llccc|}
\hline Substrate & Control & $\mathbf{5 0} \mathbf{~ m e q}$ & $\mathbf{1 0 0} \mathbf{~ m e q}$ & $\mathbf{2 0 0} \mathbf{~ m e q}$ \\
\hline WOB $* * *$ & $20.9^{\mathrm{a}}$ & $18.5^{\mathrm{a}}$ & $13.5^{\mathrm{b}}$ & $8.9^{\mathrm{d}}$ \\
$\mathbf{W B}^{* * *}$ & $22.9^{\mathrm{a}}$ & $21.4^{\mathrm{a}}$ & $19.3^{\mathrm{c}}$ & $16.1^{\mathrm{e}}$ \\
\hline
\end{tabular}

Table 2. Effect of salinity and substrate on stem cylinder diameter $(\mu \mathrm{m})$ of Phaseolus vulgaris L. Means in each row followed by different letters are significantly different $(\mathrm{p}<0.05)$. ${ }^{*}, * *, * * *$ : Differences between substrate is significant at $\mathrm{P}<0.05,0.01$, and 0.001 respectively, ns: not significant at $(\mathrm{P}<0.05)$. Interaction between substrate and $\mathrm{NaClCaCl} 2$ is not significant at $\mathrm{P}<0.05$.

there is a very significant effect of salinity on the diameter of root xylem diameter, the sand culture substrate amended with bentonite records a very significant effect compared to the sand substrate alone $(\mathrm{p}<0.05)$ (Table 1$)$.

After 21 days of culture (Fig. 4), the bean plants from $\mathrm{S}$ and $\mathrm{SB}$ respectively register a maximum diameter of the stem cylinder with 20.9 and $22.9 \mu \mathrm{m}$ by the control, on the other hand, the minimum is recorded at 200 meq of $\mathrm{NaClCaCl}_{2}$ with 8.9 and $16.1 \mu \mathrm{m}$. Overall, the sand culture substrate improved with bentonite has larger shoot diameters with 21.4 and $19.3 \mu \mathrm{m}$ than those of the $\mathrm{S}$ with 18.5 and $13.5 \mu \mathrm{m}$ respectively under salinity with 50 and 100 meq of $\mathrm{NaClCaCl}_{2}$. Statistical calculations show that there is a very significant effect of salinity on the stem cylinder diameter. The SB has a significant effect at 100 and 200 meq. However, the interaction between substrate and $\mathrm{NaClCaCl}_{2}$ is not significant at $\mathrm{P}<0.05$ (Table 2).

\section{DISCUSSION}

The salinity induced structural changes in the xylem of the stems and roots. In plants stressed with $\mathrm{NaClCaCl}_{2}$, the thickness of the shoot vascular cells was much higher than in the control; the effect of salinity depended on the salt concentration and the growing medium. Al-Tardeh \& Iraki (2013) studied the seedlings of two varieties of tomatoes exposed to salt stress and concluded that salinity reduces root vascular function. In addition, the profiles of the phloem and xylem parenchyma were significantly reduced in saline environments. Other studies confirm that the salinity of the environment modifies the anatomical structure of the root and leads to a decrease in the number of cells per xylem bundle and the number of layers of cortical parenchyma (Haouala et al., 2007; Farhana et al., 2014). In general, plants grown in bentonite-modified soil had a larger xylem vessel diameter than those grown in sand without bentonite, this is likely due to the role of calcium-rich bentonite in mitigating the effect of salinity, as pointed out by Hellal et al. (2015). These results were approved by Arbaoui (2016), with $10 \%$ bentonite in sandy soils, the effect of salinity is reduced on tomato plants. Saline stress is associated with a greater deposit of lignin in the vascular tissue and/or the development of xylem. $\mathrm{NaClCaCl}_{2}$ causes significant lignifica- 


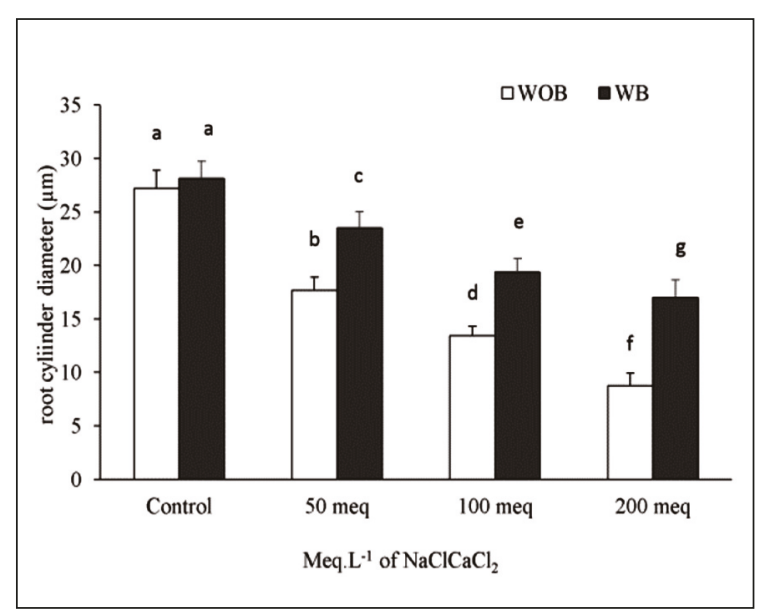

Figure 3. Root cylinder diameter $(\mu \mathrm{m})$ after 21 days of bean variety "coco rose" cultivated on substrate (S and SB) stressed with $\mathrm{NaClCaCl} 2$. Data represent the mean of tree replication and error bars indicate SD. Different letters among a groups show significantly different values at $p<0.05$. The same letters show no significantly different values.

tion in root and caular vascular tissues, suggesting a factor that inhibits root growth and, therefore, represents an adaptation mechanism to resist the stress imposed by salinity (Cachorro et al., 1993). Vascular tissue and the size of plant cells are reduced when exposed to salinity. In addition, the cross-sectional areas of the roots of plants exposed to salinity were considerably reduced, so that the roots of salt-stressed seedlings exhibited reduced vascular function and cortical parenchyma compared to control plants. These changes in the number and diameter of xylem vessels have had a significant impact on water consumption and transport according to several authors (Choat et al., 2005; Alsafary et al., 2019). According to several studies, the adaptation of plants to salt stress is accompanied by physiological changes (Shannon, 1997) and anatomical changes (Hwang \& Chen, 1995; Çavuşoğlu et al., 2007), inhibition in diameter and number of xylem. Introduced by Kiliç et al. (2007), so salinity stress induced the production of new protein bands do not occur in the control plants (see also Dawood \& El-Awadi, 2015). In addition, the salt response of plant species depends on several variables, starting with the species itself, its variety, salt concentration, growing conditions and stage of plant development (Bennaceur et al., 2001; Alaoui et al., 2013). The identification of salt tolerant varieties and genotypes, capable of mini-

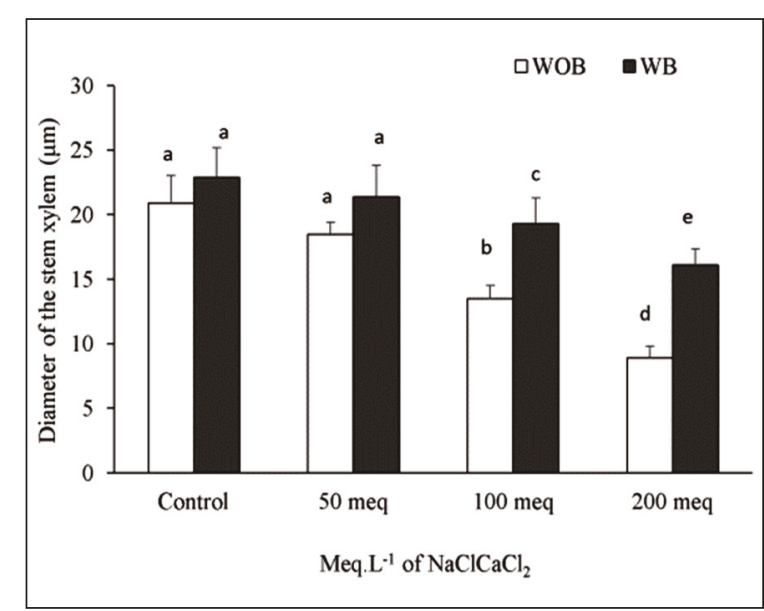

Figure. 4. Stem cylinder diameter $(\mu \mathrm{m})$ after 21 days of bean variety "coco rose" cultivated on substrate (S and $\mathrm{SB}$ ) stressed with $\mathrm{NaClCaCl}$. Data represent the mean of tree replication and error bars indicate SD. Different letters among a groups show significantly different values at $p<0.05$. The same letters show no significantly different values.

mizing the depressive effects of salinity on yields, would certainly improve agricultural production in salinity-affected areas. In non-Halophytes, there is great variability in responses of sensitive or salt stress tolerant species based on the lipid composition of the roots (Greeway, 1980). The effect of salinity on the lipid composition of roots has been studied in different species, including grapes, bean and plantago (Erdel et al., 1980). However, the mechanism of adaptation of plants to salinity is not fully known. Calcium plays a crucial role in the stabilization of cell membranes. Also, it is known to have an improving effect on plant growth stress (Hyder \& Greenway, 1965; Deo \& Kanwer, 1969; La Haye \& Epstein, 1971).

\section{CONCLUSIONS}

The presence of calcium in bentonite and in the solution of irrigation has played an important role in reducing the effect of salinity. This is due to the contribution of bentonite and the mixture of $\mathrm{NaCl}$ with $\mathrm{CaCl}_{2}$ that made it possible to improve the number of cells of the vessels of the xylem, whether it is the root or the stem. Finally, an addition of $7 \%$ bentonite to sandy soils with a saline tendency improves the structure of sandy soils. 


\section{REFERENCES}

Alaoui M.M., El Jourmi L. Ouarzane A. Lazar S. El Antri S. Zahouily M. \& Hmyene A., 2013. Effet du stress salin sur la germination et la croissance de six variétés marocaines de blé (Effect of salt stress on germination and growth of six Moroccan wheat varieties). Journal of Materials and Environmental Science, 4: 997-1004.

Alsafari S. A. Galal H. K. \& Bafeel S. O., 2019. Growth and anatomy of tomato (Solanum lycopersicum Mill.) cultivars marmande and oria under salinity stress. Pakistan Journal of Botany, 51: 1199-1207. http://dx. doi.org/10.30848/PJB2019-4(16)

An P., Inanaga S. Li X. Shimizu H. \& Tanimoto E., 2003. Root characteristics in salt tolerance. Root Research, 12: $125-132$.

Arbaoui M., 2016. Effets du stress salin sur des plantules de tomate (Lycopersicon esculentum Mill.) cultivées sur substrat sableux amendé en bentonite. Thèse de doctorat., Université d'Oran1, Algérie, 150 pp.

Al-Tardeh S. \& Iraki N., 2013. Morphological and anatomical responses of two Palestinian tomato (Solanum lycopersicon L.) cultivars to salinity during seed germination and early growth stages. African journal of Biotechnology, 12: 4788-4797. http://dx. doi.org/10.5897/AJB12.2707

Bennaceur M., Lebrun P., Billotte N., Chevallier M.-H. \& Bouguedoura N., 2001. Polymorphisme du palmier dattier (Phoenix dactylifera L.) à l'aide de marqueurs microsatellites du cocotier (Cocos nucifera L.) ou du palmier à huile (Elaeis guineensis Jacq.). VII es journées scientifi ques: Des modèles biologiques à l'amélioration des plantes. Ed Hamon S, pp 599-600.

Cachorro P., Ortiz A. \& Cerdá A., 1993. Growth, water relations and solute composition of Phaseolus vulgaris L. under saline conditions. Plant science, 95: 23-29.

Çavuşoğlu K., Kılıç S. \& Kabar K., 2007. Some morphological and anatomical observations during alleviation of salinity $(\mathrm{NaCl})$ stress on seed germination and seedling growth of barley by polyamines. Acta Physiologiae Plantarum, 29: 551-557.

Choat B., Cobb A.R. \& Jansen S., 2008. Structure and function of bordered pits: new discoveries and impacts on whole-plant hydraulic function. New phytologist, 177: 608-626. http://dx.doi.org/10.1111/j. 1469-8137.2007.02317.x

Dawood M.G. \& El-Awadi M.E., 2015. Alleviation of salinity stress on Vicia faba L. plants via seed priming with melatonin. Acta Biológica Colombiana, 20: 223-235.

Deo R. \& Kanwar J.S., 1969. Effect of saline irrigation waters on the growth and chemical composition of wheat. Journal of the Indian Society of Soil ScienceIndian Journals, 16: 365-370.

Dolotabadian A., Sanavy S.A.M.M. \& Ghanati F., 2011. Effect of salinity on growth, xylem structure and anatomical characteristics of soybean. Notulae Scientia Biologicae, 3: 41-45.

Erdel L., Stuiver B.E.P. \& Kuiper P.J., 1980. The effect of salinity on lipid composition and on activity of $\mathrm{Ca}^{2+}$-and $\mathrm{Mg}^{2+}$-stimulated ATPases in salt-sensitive and salt-tolerant Plantago species. Physiologia Plantarum, 4: 315-319.

Farhana S., Rashid P. \& Karmoker J. L., 2014. Salinity induced anatomical changes in maize (Zea mays L. cv. Bari-7). Dhaka University Journal of Biological Sciences, 23: 93-95.

Greenway H. \& Munns R., 1980. Mechanisms of salt tolerance in nonhalophytes. Annual review of plant physiology, 31: 149-190.

Haouala F., Ferjani H. \& El Hadj S.B., 2007. Effet de la salinité sur la répartition des cations $(\mathrm{Na}+, \mathrm{K}+$ et $\left.\mathrm{Ca}^{2+}\right)$ et du chlore (Cl-) dans les parties aériennes et les racines du ray-grass anglais et du chiendent. Biotechnology, Agronomy, Society and Environment, 11: 235-244.

Hellal F. A., El-Sayed S. A. A. Zewainy R. M. \& Abdelhamid M., 2015. Interactive effects of calcium and boron application on nutrient content, growth and yield of faba bean irrigated by saline water. International Journal of Plant \& Soil Science, 4: 288-296.

Hoagland D.R. \& Arnon D. I., 1938. The water-culture method for growing plants without soil. Circular (California Agricultural Experiment Station), 347: 139.

Huang J. \& Redmann R.E., 1995. Responses of growth, morphology, and anatomy to salinity and calcium supply in cultivated and wild barley. Canadian Journal of Botany, 73: 1859-1866.

Hwang Y.H. \& Chen S.C., 1995. Anatomical responses in Kandelia candel (L.) Druce seedlings growing in the presence of different concentrations of $\mathrm{NaCl}$. Botanical Bulletin of Academia Sinica, 36: 181-188.

Hyder S.Z. \& Greenway H., 1965. Effects of $\mathrm{Ca}^{++}$on plant sensitivity to high $\mathrm{NaCl}$ concentrations. Plant and Soil, 23: 258-260.

Jampeetong A. \& Brix H., 2009. Effects of $\mathrm{NaCl}$ salinity on growth, morphology, photosynthesis and proline accumulation of Salvinia natans. Aquatic Botany, 9: 181-186.

Kiliç S., Cavusoglu K. \& Kabar K., 2007. Effects of 24epibrassinolide on salinity stress induced inhibition of seed germination, seedling growth and leaf anatomy of barley. Süleyman Demirel University Faculty of Arts and Science Journal of Science, 2 : 41-52.

La Haye P.A. \& Epstein E., 1970. Calcium and salt tol- 
eration by bean plants. Physiologia Plantarum, 25: 213-218.

Munns R. \& Tester M., 2008. Mechanisms of salinity tolerance. Annual Review of Plant Biology, 59: 651681. http://dx.doi.org/10.1146/annurev.arplant.59. 032607.092911

Panta R.K., Walsh M.F. Bell S.T. Anderson N.G. Butler A.P. \& Butler P.H., 2014. Energy calibration of the pixels of spectral $x$-ray detectors. IEEE transactions on medical imaging, 34: 697-706.

Parida A.K. \& Das A.B., 2005. Salt tolerance and salinity effects on plants: a review. Ecotoxicology and Environmental Safety, 60: 324-349. http://dx.doi.org/10. 1016/j.ecoenv.2004.06.010

Pimmongkol A., Terapongtanakhon S. \& Udomsirichakhon K., 2002. Anatomy of salt and non-salt- tolerant rice treated with $\mathrm{NaCl} .28$ Congress on science and technology of Thailand, Bangkok (Thailand), 24-26 October 2002.

Qadir M., Noble A.D. Schubert S. Thomas R.J. \& Arslan A., 2006. Sodicity-induced land degradation and its sustainable management: Problems and prospects. Land Degradation \& Development, 17: 661-676. http://dx.doi.org/10.1002/ldr.751

Shannon M.C., 1997. Adaptation of plants to salinity. Advances in agronomy, 60: 75-120.

Takemura T., Hanagata N. Dubinsky Z. \& Karube I., 2002. Molecular characterization and response to salt stress of mRNAs encoding cytosolic $\mathrm{Cu} / \mathrm{Zn}$ superoxide dismutase and catalase from Bruguiera gymnorrhiza. Trees, 16: 94-99. http://dx.doi.org/10.1007/ s00468-001-0154-2 
